\title{
Consistency of Debt Policy: An Intrinsic Role of Business Group Affiliation
}

\author{
Wajiha Rasheed*, Kanwal Iqbal Khan ${ }^{* *}$, Syed Muhammad \\ Waqar Azeem Naqvi ${ }^{* * *}$ and Shahid Mahmood ${ }^{* * * *}$
}

\begin{abstract}
The debt structure remains an area of indispensable concern for businesses across the globe. The organizations are facing difficulty to achieve an optimal capital structure due to inconsistent debt policy. This study investigates the firm's debt policy consistency over a period of twenty-two years after its establishment by observing leverage, debt maturity, debt granularity, and debt specialization as important measures. It has employed a unique dataset covering all the non-financial Pakistani firms listing from 1997 to 2018. The results depict that a firm's debt policy remains remarkably consistent over time, confirming that the initially adopted debt policy is a significant determinant of its future debt policies. However, it is noteworthy that the consistency of the debt policy has shown a declining trend due to the firm's age and size. Additionally, we have examined the effect of business group affiliation on the consistency of debt policy, with further segregation in terms of the financial firm's presence in a group or not. The findings show that a group affiliated firm has more access to the debt market than an unaffiliated firm. Further, the existence of a financial firm in a group serves as an extended financial market that help them to survive in a distress situation. This study will assist the managers in understanding the significance of initial debt policy on the continuity of future policies that help them in financial decision-making.
\end{abstract}

Keywords: Leverage, debt policy, debt maturity, debt specialization, debt granularity, business group affiliation, financial decision-making.

JEL Classification: C33, G32, G34.

\footnotetext{
${ }^{*}$ Research Scholar, Institute of Business \& Management, University of Engineering and Technology, Lahore, Pakistan.

** Assistant Professor, Institute of Business \& Management, University of Engineering and Technology, Lahore, Pakistan.

**** Financial Tax Analyst, Madan CA PC, Mississauga, Canada.

***** Associate Professor, School of Business, Management and Administrative Sciences, The Islamia University of Bahawalpur, Pakistan.
} 


\section{Introduction}

Since the past few years, researchers and practitioners have been identifying the key determinants of debt persistence for the registered (Lemmon et al., 2008; Wu \& Yeung, 2012) and unregistered firms (Hanousek \& Shamshur, 2011). The literature also confirmed that an optimal capital structure could not possibly be obtained without optimizing the debt structure of the firm (Kayo \& Kimura, 2011). Previous studies claimed that the joint optimization of debt and the capital structure tends to have an impact on the firms' overall value (Martellini, Milhau, \& Tarelli, 2018). That is why firms need to be abreast with the factors that affect their debt policy to achieve an optimal debt structure. The studies by Hanssens et al. (2016) and Huang et al. (2018) show that the previously adopted debt policies of the firms, corporate governance and the macro-level systematic risk have a substantial impact on the future debt policy. Hence, the theory of imprinting, information asymmetry, and path dependence tend to support the above-mentioned phenomena (David, 1985; Stinchcombe \& March, 1965; Wu \& Wang, 2005).

However, recent studies propagate that leverage, debt maturity, debt granularity, and debt specialization are the key predictors for the debt policy of a firm (Hassens et al., 2016; Khan et al., 2021). These tools are used to set the optimized debt portfolio and also used to understand the evolution of a firm's debt policy over time. Further, it is also confirmed that a debt policy adopted at the start-up stage remains stable over a longer period of time, especially since they assume it to be optimal ( $\mathrm{Wu} \&$ Yeung, 2012). Its basic reason is that a start-up firm financed by debt is more vulnerable to bankruptcy costs due to its high volatility in returns and agency cost, leading to an inconsistent debt policy (Martellini et al., 2018).

Another identified factor is the departure or death of the founder CEO, which primarily influences the firm's debt policy. This is necessary because the CEO typically holds more power over the financial decision making of the firm (Hanssens et al., 2016). The credibility of the CEO impacts the consistency of the debt policy. Particularly, if the founder CEO remains attached to the firm, it generally follows the same pattern and even the debt composition as determined at the start-up time. Robb and Robinson (2014) stated that the new firms depend more on debt financing than frequently perceived. Moreover, there are several other identified factors such as ownership structure (Kieschnick \& Moussawi, 2018), taxes and tax shelters (Liu et al., 2019), growth opportunities (Khan et al., 2017) that affects the stability of corporate debt policy. However, there are various other less explored aspects in the literature that can possibly affect the corporate debt 
policy, like business group affiliations, macroeconomic factors, and firm characteristics that can affect the debt-related decisions, but their role is less explored in the literature.

In the context of emerging markets, studies claimed that the business group affiliation plays a vital role in aiding other affiliates (Jara et al., 2018). Since the affiliates are usually subsidiaries of the holding company, it is expected that the parent company holds more power over their financial decisions (Fan et al., 2016). In addition to this, the debt structure further tends to vary due to the influence of the financial firm in the affiliated business group. It happens because their affiliates serve as an internal capital market and provide them with inter-business loans (Jara et al., 2018), especially at the time of financial distress. This understanding creates the basis for this study to investigate their effect on the firms' debt policy consistency and add to an emerging debate regarding debt structure policies. Therefore, the purpose of this study is to explore the consistency of a firm's debt policy over time. It specifically focuses on how the initially adopted debt policy of the firm is consistent for the proceeding years. Moreover, this study also analyzes the impact of business group affiliation on the consistency of the firms' debt policies.

The current study contributes to the literature in several ways. Firstly, it contributes towards the enrichment of the corporate finance literature. In more specific terms, it focuses on the various aspects of debt financing, primarily because of the knowledge provided for the consistency of the firms' debt policy. Secondly, this study is intended to investigate the role of the business group affiliation, mainly in emerging markets. It further sheds light on the significant influence of the financial firms' affiliation on the consistency of debt policy. Finally, it considers the whole population of the non-financial firms, which adds as a remarkable contribution of this study towards the relevant literature, as it portrays the real and bigger picture of the firms' debt policy consistency, that too within the different nature of the businesses.

This study is organized in the following manner: the next section consists of the literature review of the relevant theoretical and empirical work of the capital structure, debt policy, business group affiliations, firm characteristics. Following this, the third section contains the research methodology, including the data collection methods, sample descriptions, relevant measures, data analysis tools and the model specification. The fourth section focuses on the data analysis, which includes the descriptive statistics and the statistical results of the research question. Finally, section five 
discusses the data analysis results, implications, and the conclusion of the study, followed by the proposed future direction and limitations of the study.

\section{Literature Review}

\subsection{Capital Structure and Debt Policy}

Corporate finance revolves around maximizing shareholder's wealth by acquiring and allocating capital effectively (Welch, 2004). The capital structure deals with mixing debt and equity, which is concerned with the capital acquisition side of corporate finance (Khan et al., 2016). Although, these sources of finance can positively impact the firm value and the wealth of shareholders. Debt financing is considered a cost-effective method to fulfil the investment requirement of firms, but a gradual increase in the debt level will increase the financial risk and cash flow volatility. This is the main reason for the firm to take such decisions after the cost and benefit trade-off analysis. Since the notable work of Modigliani and Miller (1958) was published, the concept of capital structure turned into a subject of extraordinary research. Debt structure, being a component of capital structure, further comprises of various debt instruments, which have still managed to be less explored in the extant literature. Modigliani and Miller (1963) presented the capital structure theory by featuring the significance of external financing (debt).

Tax shields have been distinguished to be a noteworthy advantage of debt financing. Although, debt financing may likewise also bring about certain costs with it. These costs include insolvency costs (Liu et al., 2019), monitoring and information costs (Goodell \& Goyal, 2018), and agency costs (Ni et al., 2017), among others. In order to achieve an ideal debt portfolio, financial managers face the challenge of balancing the trade-off of each type of debt instrument. Hence, the ideal debt structure limits a firm's liquidation cost and ultimately protects the company from default (Berlin et al., 2020). Recently, several studies have contributed towards the literature pertaining to debt structure, where they have focused on the reasons for changes in the debt structure. Likewise, when firms come face to face with financial distress, they undergo considerable differences in their previous debt structure, mainly by refinancing their operations (Dudley \& Yin, 2018). Moreover, even the external economic distress effects are not only limited to the financial decision. In fact, they also affect the debt maturity settings under the agency cost approach (Casino-Martínez et al., 2018).

Similarly, the firm size affects the firm's financial decision, which pertains to which debt financing instrument should be used for 
incremental financing. Here, the large firms are more likely to resort to public debt than the smaller firms, which refer to the non-bank private loans or bank loans (Alfaro et al., 2019). The literature also provides evidence of the choice of debt financing, specifically from the prospect of firm performance. This can be applied whether the firm uses the debt in the name of a business or owner of the start-up, where the start-up firms with better execution prospects utilize the business debt (Cole \& Sokolyk, 2018). Moreover, the different composition of debt in a firm's capital structure may also affect its performance. This is primarily because of a higher level of bank debt, which will increase the firms' performance due to the monitoring factor of banks (La Rosa et al., 2018).

Moreover, in the past few years, researchers have become more interested in the persistence of the debt structure over the time span. In this regard, their findings support multiple theories (Khan et al., 2016). Furthermore, in their study, Stinchcombe and March (1965) proposed the imprinting theory, which claims that a firm imprints their initially adopted policies throughout their life cycles, even when the environment of the industry changes (Hanssens et al., 2016). On the contrary to the imprinting theory, David (1985) proposed the path dependence theory. This theory suggests that the initial advantage of the policy is also likely to stay intact in the later stages of their business life cycle, mainly due to the lethargic effect. In reflection to the path dependence theory, this study also confirms that the initial policies continue to leave an impact on the future financial decisions of a firm. Since the previous condition of financing is a major influencing factor of a firm's future decision making (Ghouma, 2017).

Hence, the path-dependence theory underlines the significant and historical impact of the initial debt policy and stresses its role in time. This pair provides strong evidence with regards to the constructive effects that have been observed on future debt policies. Eventually, with time more studies have supported this notion of debt policy consistency, particularly since the year 2008. However, the geographical context is majorly skewed towards the developed nations compared to the developing countries. As a result, it is more encouraging to study this concept in the unique environment of Pakistan.

\subsection{Business Group Affiliation and Debt Policy Consistency}

Since some time now, scholars and practitioners have been studying the different dimensions of group affiliation in developing economies (Hu et al., 2019; Joni et al., 2020). This part of the literature focuses on reviewing the 
available research, mainly based on the firms' capital structure, especially about the business group affiliated firms. It is noteworthy that business groups are generally formed to gain access to the internal capital market and comprehend market control and inadequate information through different business portfolios (Gaur et al., 2019). Business groups collectively aid the affiliated firms in financial crisis through intra-group financing, inter-party transactions, asset procurement and guarantee of loans. The aforementioned factors make the internal capital market in a business group (Choi et al., 2019). Different studies have concluded that financing decisions of business groups affiliates are usually determined by inter-party transactions and loan guarantees (Kim et al., 2019; Lin \& Yeh, 2020).

The internal capital market reduces the weak affiliates' dependence on bank loans. This especially holds true when the financing cost is high due to uncertainty in the environment. The same rule applies to the firms affiliated with large business groups that enjoy the access to multiple alternative sources of financing (Khatua, 2017). In the emerging markets, the firm which receives more intra-business loans, so as to achieve their targeted level of leverage, are more likely to diversify their debt portfolio. Hence, the business group affiliates are more likely to resort to debt specialization, as compared to the non-affiliated firms (Malik \& Afza, 2016).

When further demonstrating the limited information and market imperfection difficulties, and their effect on group affiliated firm's leverage, (Borda et al., 2017) observed that the behaviour of business group affiliated firms follow a significantly different financing decision criteria as compared to the stand-alone firms. Therefore, the internal debt market and bank loans tend to be a more persistent type of debt method used in bankaffiliated business group firms (Ellouze \& Mnasri, 2020).

When the business groups enjoy the perks of affiliation, they also face the negative impact of business group affiliation on the profitability of the newly established firm. This phenomenon is compared to the stands alone firms that exist without any affiliation, as the intra-group transaction and expense, borne by the affiliated firms, erode the profitability of the firm. Here, they also face the adverse spillover effects, as a firm in a group setting faces a down-rating due to the financial constraints which further affect the value of the whole business group, regardless of the number of firms in the group, their size, and level of diversification (Kwon et al., 2016). In this regard, the reviewed literature suggests that the business group affiliation tends to have a possible influence on the debt structure of their affiliates, and it is worthy of investigating its impact on the consistency of a firm's debt policy. 


\section{Methodology}

This study is based on the quantitative research method, which is usually suitable for research in finance, where the object data is used to analyze the hypothesis or ground theory. The objective of the study is to investigate the effect of firm's initial debt policy on the consistency of its future debt policy. It observes diverse variables in which four instruments of firm debt policy (leverage, maturity, granularity and specialization), dummy of business group affiliation and financial firm affiliation in the group, are considered. Data is collected for all firms listed with the Pakistan stock exchange since 1997 till 2018. The panel data is used since the consistency of debt policy is analyzed for twenty-two years.

\subsection{Population and Sample}

This study has considered the firms listed at the Pakistan Stock Exchange throughout the time span of this study (1997-2018) as these organizations are obliged to publish their yearly reports. However, it follows certain sample selection rules by keeping in mind the objectives of the study. First, it exclude the financial firms from the sample. The companies are categorized into two classes: the borrower and lender as for debt policy. As the focus of the present study on the debt policy of the firms , therefore, loan providing companies are omitted. Since the loan providing firms mostly depends on deposits to back their operations and are subject to the regulation provided by government, mainly concerning their capital structure. That is why excluded from the population. Approximately, from the whole population of listed companies, around 180 organizations counting for banks, investment, insurance, and other financial organizations are omitted from the study population.

Second, It is also noteworthy that the number of listed companies accounted different every year due to the liquidation and delisting, mainly for not satisfying the prerequisites of SECP, and also not fulfilling the laws of the Companies Ordinance 1984. This count also varies due to the new listing of the organizations, mergers and demergers. The absolute number of firms tends to vary due to these restrictions, and subsequently make an unbalanced panel data. Furthermore, this is transformed into a balanced panel data, as per the current study requirement, by excluding the firms that are either listed after the year 1997 or delisted during the time span. That is why, it intended to include only those non-financial firms remains listed on the Pakistan stock exchange throughout the time span of this study (1997-2018), which gives a total count of 315 companies. 


\subsection{Data Collection}

The data was collected from secondary sources for a total time span of 22 years, starting from 1997 till 2018. This source is also appropriate according to the need of this research design, and it is also an easily accessed and cost-effective method. The secondary data for selected companies are obtained from different sources from the year 1997 till 2018. Firstly, the primary source for the data collection is the annual reports of the company as it provides first hand accurate and reliable information about the firm because they are prepared according to the IAS (International Accounting Standard) and the Companies Ordinance of 1984. Secondly, the data on firm-level factors and industry is collected from the analysis reports of PSX (Pakistan Stock Exchange). Thirdly, the data for business group affiliation is assembled from the annual reports and the information provided on the official websites of the companies. In addition to this, the balanced panel data has been used due to the requirement of the debt policy consistency analysis. The measures of the study variables have been mentioned in Table 1.

\subsection{Measurement}

In order to examine the consistency of the firms' initial debt policy, the random effect regression has been resorted to. Thus, the estimate used has been mentioned below.

$$
Y_{i, t}=\alpha_{0}+\alpha_{1} X_{1, t}+\mu_{i, t}
$$

Where, $Y_{i, t}$ represents the firms existing debt policy, $X_{1, t}$ represents the firms debt policies of the firms over years, and $\mu_{i, t}$ denotes the error term. Thus, the model that has been used for this is formulated as follows:

$$
Y_{i, t}=\beta_{0}+\beta_{1} X_{1, t}+\beta_{2} X_{2, t}+\mu_{i, t}
$$

Where $Y_{i, t}$ is the firms' future debt policy, and $X_{1, t}$ represents the initial debt policies of the firms over years that are affiliated with a business group. Also, $X_{2, t}$ denotes the non-business group affiliated firms.

In addition to this, the influence of the financial firm affiliation in a business group on firm debt policy has been analyzed for each future year. Hence, the following estimate has been used to analyze the following function: 


$$
Y_{i, t}=\gamma_{0}+\gamma_{1} Z_{1, t}+\gamma_{2} Z_{2, t}+\mu_{i, t}
$$

Where $Y_{i, t}$ is the firms' future debt policy, and $Z_{1, t}$ represents the initial debt policies of the firms affiliated with a financial firm in a business group. Moving on, $Z_{2, t}$ represents a business group affiliated firm which does not has any financial firm in its group.

Table 1 shows the definition of the variables used in the study along with their measurements.

\section{Table 1: Variables and Measurements}

\begin{tabular}{|c|c|c|}
\hline Variables & Definition & Author \\
\hline \multicolumn{3}{|l|}{ 1.Dependent variables } \\
\hline Leverage & Total debt/total assets & $\begin{array}{l}\text { Koralun-Bereźnicka, } \\
\text { (2018) }\end{array}$ \\
\hline Debt specialization & $\begin{array}{l}\text { Herfindahl-Hirschman } \\
\text { Index of debt usage }\end{array}$ & Khan et al., (2021) \\
\hline Debt maturity & $\begin{array}{l}\text { The ratio of long-term } \\
\text { debt to total debt }\end{array}$ & Benlemlih, (2017) \\
\hline Debt granularity & $\begin{array}{l}\text { Herfindahl-Hirschman } \\
\text { Index of debt maturity }\end{array}$ & $\begin{array}{l}\text { Norden, Roosenboom, } \\
\text { and Wang, (2016) }\end{array}$ \\
\hline \multicolumn{3}{|l|}{ 2.Independent variable } \\
\hline Leverage at start-up & Value of the first year & $\begin{array}{l}\text { Siqueira, Guenster, } \\
\text { Vanacker, and Crucke, } \\
\text { (2018) }\end{array}$ \\
\hline Debt specialization at start-up & Value of the first year & Hassens et al, (2016) \\
\hline Debt maturity at start-up & Value of the first year & Hassens et al, (2016) \\
\hline Debt granularity at start-up & Value of the first year & Hassens et al, (2016) \\
\hline \multicolumn{3}{|l|}{ 3.Emerging market Variables } \\
\hline Business group affiliation & $\begin{array}{l}\text { If the firm is affiliated, } \\
\text { then } 1 \text { otherwise } 0\end{array}$ & Khan et al., (2017) \\
\hline Financial firm affiliation & $\begin{array}{l}\text { If the firm is affiliated } \\
\text { with a financial firm, } \\
\text { then } 1 \text { otherwise } 0\end{array}$ & Khan et al., (2017) \\
\hline \multicolumn{3}{|l|}{ 4.Firm characteristics } \\
\hline Firm size & Ln (total sales) & $\begin{array}{l}\text { Walthoff-Borm, } \\
\text { Schwienbacher, and } \\
\text { Vanacker, (2018) }\end{array}$ \\
\hline Profitability & Net Profit/total assets & $\begin{array}{l}\text { Alderson et al., } \\
(2014)\end{array}$ \\
\hline Tangibility & Net PPE/total assets & $\begin{array}{l}\text { Deloof and Vanacker, } \\
\text { (2018) }\end{array}$ \\
\hline
\end{tabular}




\begin{tabular}{|c|c|c|}
\hline Variables & Definition & Author \\
\hline Firm Growth & $\begin{array}{l}\text { Market Value of } \\
\text { Equity/Book Value of } \\
\text { Equity }\end{array}$ & $\begin{array}{l}\text { Povoa and Nakamura, } \\
\text { (2014) }\end{array}$ \\
\hline Liquidity & $\begin{array}{l}\text { Cash and Short - Term } \\
\text { Investments/ } \\
\text { Total assets }\end{array}$ & $\begin{array}{l}\text { Danis, Rettl, and } \\
\text { Whited (2014) }\end{array}$ \\
\hline Default Risk & $\begin{array}{l}\text { Altman Z- } \\
\text { Score }=\left[1.2^{*}((\text { Working }\right. \\
\text { Capital)/(Total Assets) })] \\
+\left[1.4^{*}((\text { Retained }\right. \\
\text { Earnings }) /(\text { Total } \\
\text { Assets) })+ \\
{\left[3.3^{*}(\text { EBIT / (Total }\right.} \\
\text { Assets) })]+\left[0.6^{*}((\text { Market }\right. \\
\text { Value of Equity)/ (Total } \\
\text { Liabilities)) + [999* } \\
(\text { Sales/(Total Assets }))]\end{array}$ & $\begin{array}{l}\text { Alderson et al., (2014); } \\
\text { Wang \& Lin (2013) }\end{array}$ \\
\hline Dividend Policy & $\begin{array}{l}\text { Annual Dividend/ } \\
\text { Current Stock Price }\end{array}$ & $\begin{array}{l}\text { Graham, Leary and \& } \\
\text { Roberts (2015) }\end{array}$ \\
\hline
\end{tabular}

\section{Results and Discussion}

\subsection{Descriptive Statistics}

The summary statistics of this study involve the descriptive statistics of the debt policy, the initial debt policy, and the firm characteristics. All these study variable groups are further analyzed with the business group affiliation and the financial firm affiliation. The descriptive statistics used in this study are the mean and standard deviation exhibited in Table 2. Moreover, the descriptive statistics of the debt policy of all the non-financial firms from 1997 till 2018, which are not affiliated with a business group, have also been given. In addition to this, the average leverage for all the firms which are non-affiliated with a business group, affiliated with a business group, and the non-financial firm affiliation in a business group and the financial firm affiliation in a business group happens to be $58.8 \%$ (58.8\%, $62.4 \%$ and $57 \%)$, respectively.

The prevailing debt maturity in all the cases is taken to be approximately two years. Where the extent to which a firm stretches its debt maturity is $51 \%(41.8 \%, 38.7 \%$ and $43.3 \%)$ and the debt specialization is $48.6 \%$ (42.7\%, $43.3 \%$ and $42.4 \%)$. The descriptive statistics of the initial debt policy for all four cases show the average initial leverage to be $66.2 \%$ $(62.1 \%, 64.3 \%$ and $60.9 \%)$. The prevailing initial debt maturity is 
approximately two years, and the extent to which a firm stretches its debt maturity is $48 \%(38.8 \%, 32.8 \%$ and $41.8 \%)$, and the debt specialization is $42.4 \%(36.5 \%, 35.3 \%$ and $37 \%)$.

The descriptive statistics of firm characteristics for all the four cases show the firms' tangible assets of $63 \%$ (64.7\%, 67.4\% and 63.2). Moreover, they have an average book value of sale of 3.025 million $(3.063,2.938$ and 3.129 million), while the average liquidity is $1.674(1.823,1.615$ and 1.935$)$ for each liability. The profitability for the firms is at $18.9 \%(12.7 \%, 18.8 \%$ and $13.1 \%$ ) with a growth of approximately $4 \%(3.3 \%, 2.9 \%$ and $3.6 \%)$. In addition to this, the default risk is -0.139 (2.341, 2.865 and 0.204$)$, and the lower value of the default risk indicates that there are greater chances of bankruptcy, while in the current study, the firms are more vulnerable to default risk. Also, the dividend yield is at $8 \%(12.2 \%, 4.2 \%$ and $16.7 \%)$, respective of the stock market value.

Moving on, the descriptive statistics of the initial firm characteristics for all the four cases of firms shows that the firm initial tangible assets are $52 \%(51.4 \%, 54.1 \%$ and $50 \%)$, and they have an initial average book value of sale as 2.727 million (2.770, 2.721 and 0.280 million). Moreover, the average initial liquidity is $0.049(0.099,0.098$ and 0.1$)$ for each of the liabilities. Furthermore, the initial profitability for these firms is $3.5 \%(2.3 \%$, $3 \%$ and $1.9 \%$ ) with the initial growth of approximately $8.6 \%(6.5 \%, 9.1 \%$ and $5 \%)$. In addition to this, the initial default risk is $1.148(2.109,1.698$ and 0.233 ), which shows more vulnerability to the default risk. Also, their initial dividend yield is at a rate of $3.8 \%(4.3 \%, 3.5 \%$ and $4.8 \%)$, respective of the stock market value.

Table 3 shows the consistency of the debt policy with the initial debt policy, firm characteristics, and initial firm characteristics. Furthermore, the correlation between them is also analyzed for the firms which are not affiliated with a particular business group, are affiliated with a business group, affiliated with a business group exclusive of a financial firm, and affiliated with a business group inclusive of a financial firm in the group. The correlation of leverage with the initial leverage tends to become less significant when a firm is a business group affiliated, but it gets more significant when there is a financial firm in the group. Also, the correlation of debt maturity (debt specialization and debt granularity) becomes less significant when the firm is affiliated with a business group and even more when affiliated with a financial firm in the group. 


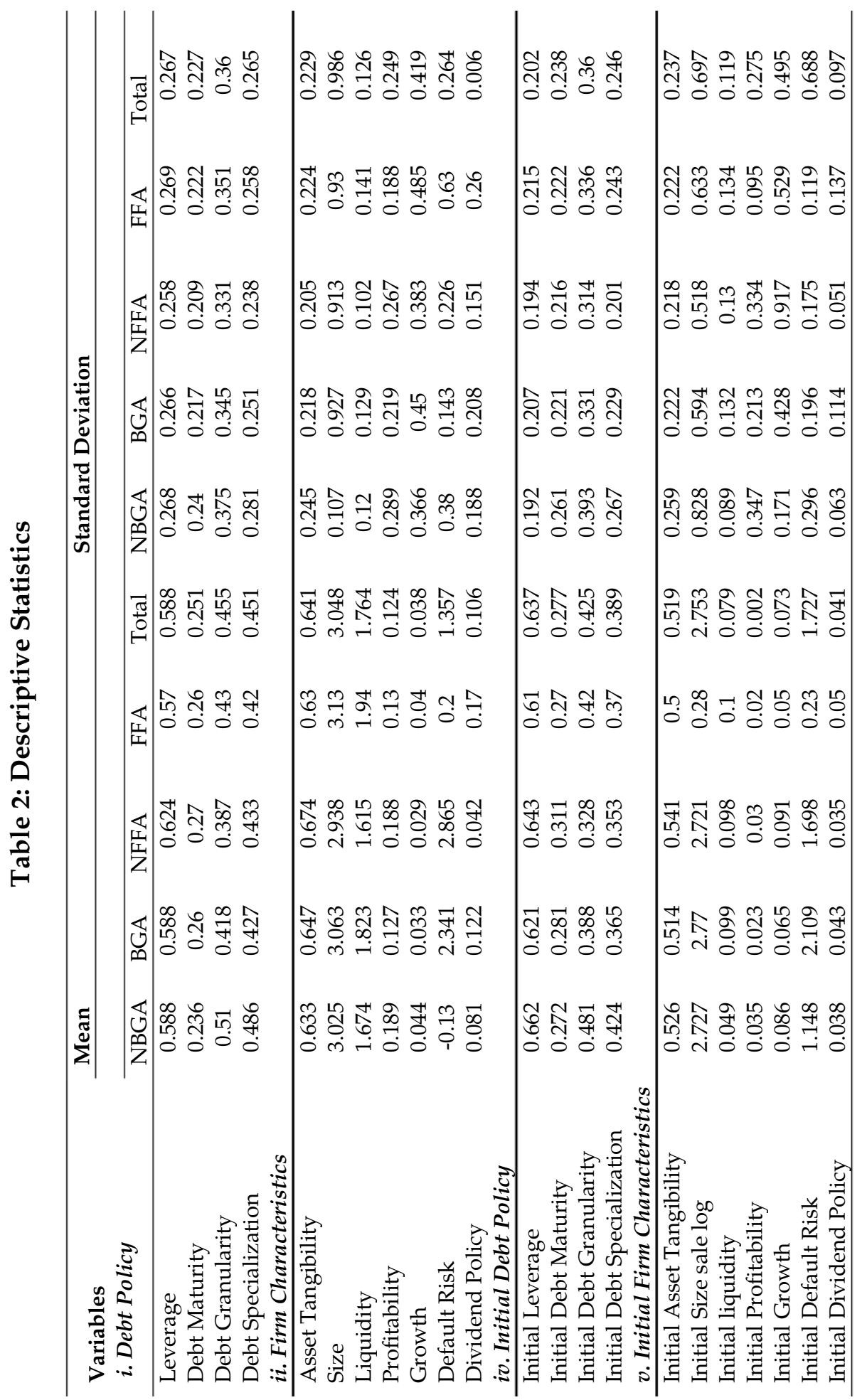




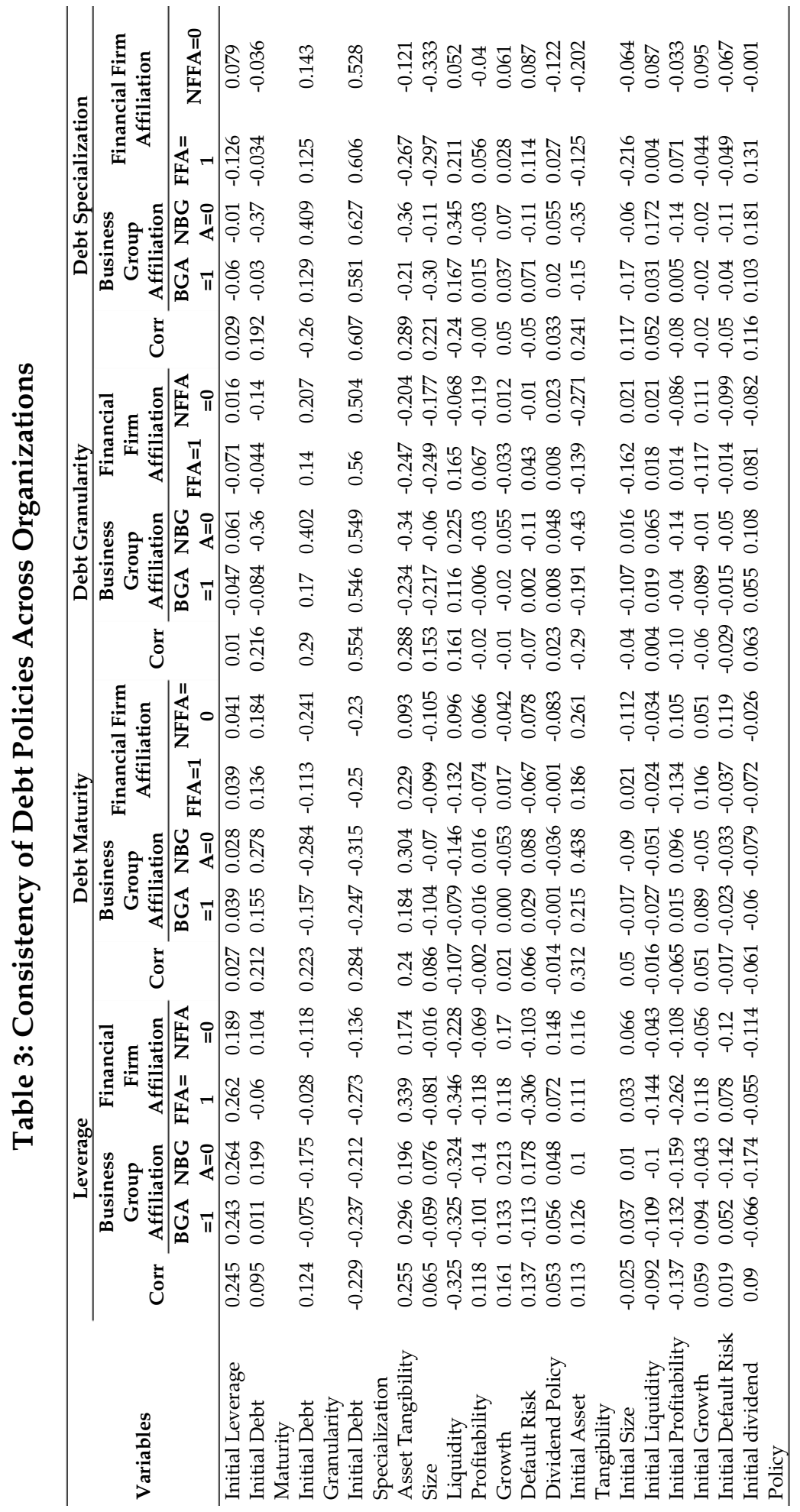




\subsection{Consistency of Debt Policy Over Years}

The main purpose of this study has been to analyze if a firm's initial debt policy is consistent over the succeeding years. In this regard, we have examined the consistency of a firm's initial debt policy by making use of the random effect regression model. The estimate that has been used is mentioned below.

$$
Y_{i, t}=\alpha_{0}+\alpha_{1} X_{1, t}+\mu_{i, t}
$$

For all the dependent Variables that have been taken into consideration (Leverage, Debt Maturity, Debt Granularity and Debt Specialization), we have estimated the respective independent variables from the initial debt policy. Also, the initial debt policy is considered as the value for year 1997, and the regression analysis is done for each consecutive year starting from 1998 till 2018. In addition to this, Table 4 shows that there is a significant impact of a firm's initial debt policy (Leverage, Debt Maturity, Debt Granularity and Debt Specialization) on the future debt policy, which is aligned with the results of (Hanssens et al., 2016).

Moreover, the results also show that a firm's initial debt policy is also persistent for the following years from the stage of the start-up. It is also noteworthy that this finding is also similar with the results of (Huang et al., 2018). Where the results also indicate that the firms' initial debt policy is consistent over the years. However, the observed trend in the findings suggests that the consistency is deteriorating as the firm starts aging (Kieschnick \& Moussawi, 2018). The debt specialization was a critically recommended debt policy, so as to consider while studying the consistency. However though, it creates a limitation for this study because of the unavailability of data, as the data was only available from the year 2009 and onwards. 
Table 4: Consistency of Firm Debt Policy Over Years

\begin{tabular}{|c|c|c|c|c|}
\hline Year & Leverage & Debt Maturity & Debt Granularity & Debt Specialization \\
\hline \multirow[t]{2}{*}{1998} & $0.886^{* * *}$ & $0.771^{* * *}$ & $0.782^{* * *}$ & \\
\hline & {$[-0.026]$} & {$[0.033]$} & {$[0.034]$} & \\
\hline \multirow[t]{2}{*}{1999} & $0.803^{* * *}$ & $0.692^{* * *}$ & $0.722^{* * *}$ & \\
\hline & {$[-0.040]$} & {$[0.036]$} & {$[0.041]$} & \\
\hline \multirow[t]{2}{*}{2000} & $0.721^{* * *}$ & $0.640^{* * *}$ & $0.636^{* * *}$ & \\
\hline & {$[0.043]$} & {$[0.043]$} & {$[0.046]$} & \\
\hline \multirow[t]{2}{*}{2001} & $0.654^{* * *}$ & $0.542^{* * *}$ & $0.519^{* * *}$ & \\
\hline & {$[0.045]$} & {$[0.044]$} & [0.049] & \\
\hline \multirow[t]{2}{*}{2002} & $0.614^{* * *}$ & $0.478^{* * *}$ & $0.481^{* * *}$ & \\
\hline & {$[0.049]$} & {$[0.046]$} & [0.049] & \\
\hline \multirow[t]{2}{*}{2003} & $0.505^{* * *}$ & $0.419^{* * *}$ & $0.463^{* * *}$ & \\
\hline & {$[0.053]$} & {$[0.045]$} & {$[0.053]$} & \\
\hline \multirow[t]{2}{*}{2004} & $0.487^{* * *}$ & $0.391^{* * *}$ & $0.515^{* * *}$ & \\
\hline & {$[0.053]$} & {$[0.042]$} & {$[0.050]$} & \\
\hline \multirow[t]{2}{*}{2005} & $0.457^{* * *}$ & $0.350^{* * *}$ & $0.483^{* * *}$ & \\
\hline & {$[0.055]$} & {$[0.042]$} & {$[0.053]$} & \\
\hline \multirow[t]{2}{*}{2006} & $0.449^{* * *}$ & $0.264^{* * *}$ & $0.382^{* * *}$ & \\
\hline & {$[0.054]$} & {$[0.039]$} & {$[0.051]$} & \\
\hline \multirow[t]{2}{*}{2007} & $0.414^{* * *}$ & $0.283^{* * *}$ & $0.364^{* * *}$ & \\
\hline & {$[0.057]$} & {$[0.041]$} & {$[0.051]$} & \\
\hline \multirow[t]{2}{*}{2008} & $0.378^{* * *}$ & $0.358^{* * *}$ & $0.443^{* * *}$ & \\
\hline & {$[0.055]$} & {$[0.042]$} & [0.052] & \\
\hline \multirow[t]{2}{*}{2009} & $0.501^{* * *}$ & $0.350^{* * *}$ & $0.313^{* * *}$ & \\
\hline & [0.069] & [0.055] & {$[0.050]$} & \\
\hline \multirow[t]{2}{*}{2010} & $0.508^{* * *}$ & $0.323^{* * *}$ & $0.312^{* * *}$ & $0.839^{* * *}$ \\
\hline & [0.068] & [0.055] & {$[0.050]$} & [0.025] \\
\hline \multirow[t]{2}{*}{2011} & $0.495^{* * *}$ & $0.275^{* * *}$ & $0.316^{* * *}$ & $0.808^{* * *}$ \\
\hline & [0.064] & [0.053] & [0.049] & [0.033] \\
\hline \multirow[t]{2}{*}{2012} & $0.467^{* * *}$ & $0.245^{* * *}$ & $0.304^{* * *}$ & $0.749^{* * *}$ \\
\hline & [0.068] & [0.054] & [0.048] & [0.036] \\
\hline \multirow[t]{2}{*}{2013} & $0.441^{* * *}$ & $0.234^{* * *}$ & $0.247^{* * *}$ & $0.681^{* * *}$ \\
\hline & [0.073] & [0.055] & {$[0.050]$} & {$[0.040]$} \\
\hline \multirow[t]{2}{*}{2014} & $0.382^{* * *}$ & $0.134^{* * *}$ & $0.236^{* * *}$ & $0.510^{* * *}$ \\
\hline & [0.073] & [0.052] & [0.049] & [0.052] \\
\hline \multirow[t]{2}{*}{2015} & $0.364^{* * *}$ & $0.045^{* *}$ & $0.225^{* * *}$ & $0.458^{* * *}$ \\
\hline & [0.072] & [0.052] & [0.049] & [0.052] \\
\hline \multirow[t]{2}{*}{2016} & $0.160^{* * *}$ & $0.114^{* * *}$ & $0.222^{* * *}$ & $0.399^{* * *}$ \\
\hline & {$[0.067]$} & {$[0.046]$} & [0.049] & {$[0.061]$} \\
\hline \multirow[t]{2}{*}{2017} & $0.157^{* * *}$ & $0.140^{* * *}$ & $0.234^{* * *}$ & $0.427^{* * *}$ \\
\hline & [0.065] & [0.052] & [0.053] & {$[0.058]$} \\
\hline \multirow[t]{2}{*}{2018} & $0.126^{* * *}$ & $0.162^{* * *}$ & $0.241^{* * *}$ & $0.451^{* * *}$ \\
\hline & {$[0.070]$} & [0.050] & [0.041] & {$[0.055]$} \\
\hline
\end{tabular}

Note: ${ }^{* *},{ }^{* *}$, and ${ }^{*}$ denote statistical significance at the $1 \% ; 5 \%$ and $10 \%$ level, respectively 


\subsection{Impact of Business Group Affiliation on the Consistency of Firm's Debt Policy}

The impact of the business group affiliate ion on the firm debt policy consistency has been analyzed using the random effect regression model. This has also been repeated for each consecutive year with the dummy variable of the business group affiliation. Therefore, the model used for this has been formulated as the following:

$$
Y_{i, t}=\beta_{0}+\beta_{1} X_{1, t}+\beta_{2} X_{2, t}+\mu_{i, t}
$$

Where $Y_{i, t}$ is the firms' future debt policy, and $X_{1, t}$ represents the initial debt policies of the firms over years that are affiliated with a business group. Also, $X_{2, t}$ represents the non-business group affiliated firms over the period of 1997-2018. In this regard, the table 5 shows the results for the impact of the business group affiliation (exclusive of a financial firm affiliation), and for the non-business group affiliated firms. The results of these indicate that the initial debt policy (leverage, debt maturity, debt granularity) for the business group affiliated firms has been deteriorating at a higher rate. Except in the case of debt specialization, the declining rate of the non-business group affiliated firms tends to be higher than the affiliated firms. This also indicates that the business group affiliated firms are more focused towards debt specialization. 


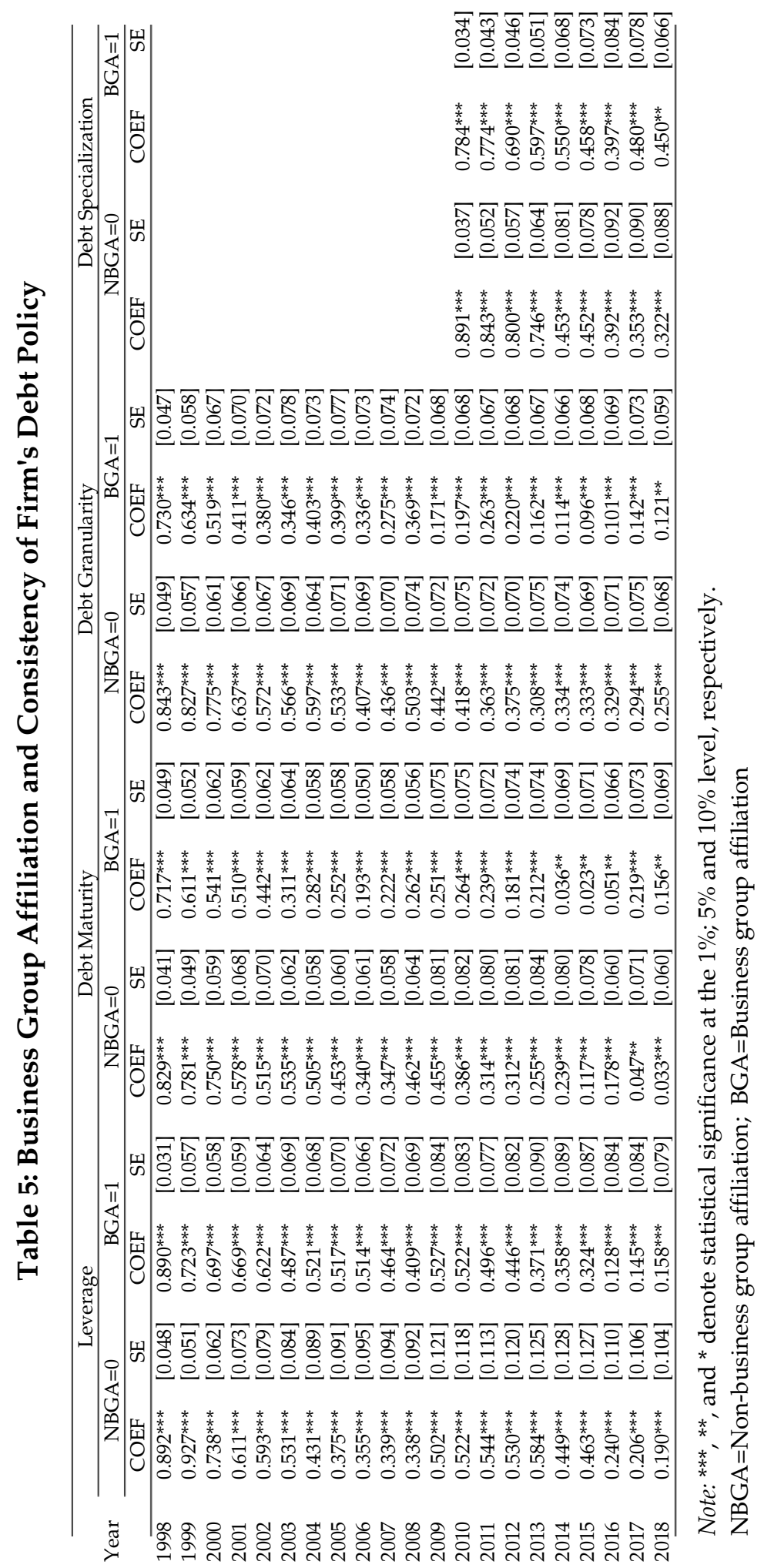




\subsection{Influence of Financial Firm Affiliation in the Business Group on the Firm's Debt Policy Consistency}

In this study, the influence of the financial firm affiliation in a business group on the firm debt policy has been analyzed for each future year. Hence, the following estimate has been used to analyze this;

$$
Y_{i, t}=\gamma_{0}+\gamma_{1} Z_{1, t}+\gamma_{2} Z_{2, t}+\mu_{i, t}
$$

Where $Y_{i, t}$ is the firms' future debt policy, and $Z_{1, t}$ represents the initial debt policies of the firms affiliated with a financial firm in a business group. Moving on, $Z_{2, t}$ represents a business group affiliated firm which does not has any financial firm in its group. Following this, the results in Table 6 show that the consistency of the firm leverage, debt maturity and debt granularity is more significant for the firms that are affiliated with the financial firms in the group, as compared to the non-financial firms that are affiliated. Also, in this case, it must also be noted that the rate of decline in the consistency is slower. However, the firms affiliated with a financial firm in the group are less debt specialized than the non-financial firm affiliation. Although the decline rate is again slower in this case. 


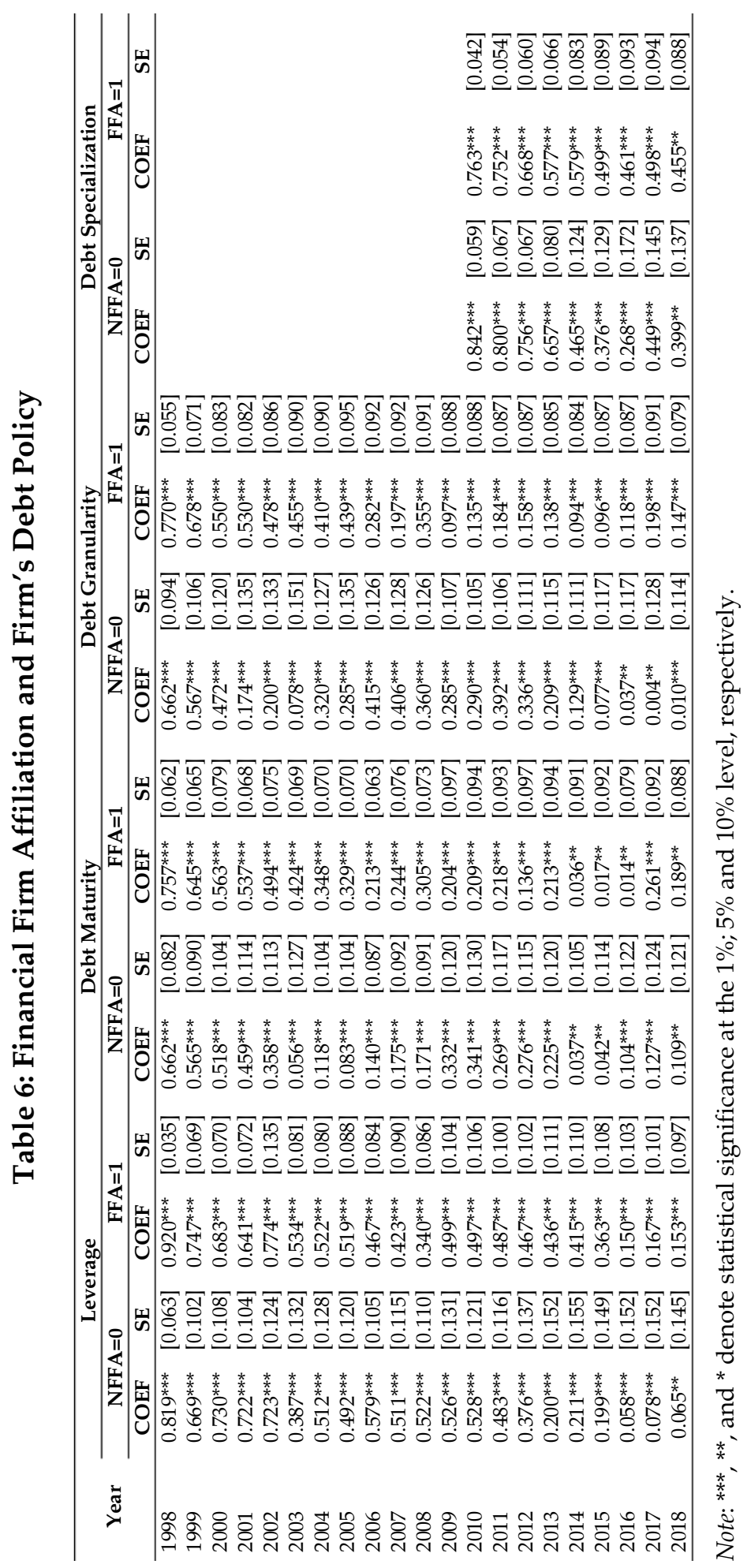




\section{Research Implications}

This study provides an in-depth insight into the impact of a firm's initial debt policy, which is further explored in the context of emerging market trends, specifically for business group affiliated firms. Moreover, the impact of the external environment is also analyzed on the relationship of the firms' initial debt policy and the future debt policy. Hence, this study contributes towards different mainstreams. Firstly, it contributes towards the advancement of the literature of corporate finance. This is primarily because of the extensive knowledge regarding the consistency of firm's debt financing, which is broadening the literature base of the capital structure, particularly for the non-financial firms.

Secondly, this study is also intended to reveal the impact of business group affiliation in the market and shed light on the significant influence of a financial firm's affiliation on the stability of the debt policy. Thus, the financial firm affiliation will be more appealing for the firms, primarily because the affiliates' debt policy shows more consistency than the nonaffiliates. Thirdly, it has considered the settings of a developing country to check the consistency of the debt policy. This is because developing countries usually have evolving financial markets, weak legal and economic systems. Finally, it considers the whole population of nonfinancial firms, which is a remarkable contribution of this study. It will portray the real and bigger picture of firms' debt policy consistency within the different nature of the businesses.

\section{Conclusions}

This study confirms the consistency of wide-ranging debt policies for all the enterprising firms from their establishment. Moreover, this investigation depends on a unique dataset, considering the whole population of non-financial firms. These firms remained listed with the Pakistan stock exchange from 1997 until 2018, which makes the time series pertaining to 22 years after establishment. The findings suggest that the firm leverage, debt maturity, debt granularity, and debt specialization strategies contain significant consistent elements that have remained intact after 22 years of establishment. However, the observed pattern shows that the consistency is declining as the firms get older. In particular, the policies adopted at the time of establishment tend to become solid indicators of future financing choices. 
Interestingly, this is the case even after analyzing that the conventional contemporaneous debt structure factors, for example, the firm size, asset tangibility, firm growth, liquidity, profitability, default risk and the dividend policy. In addition to this, the findings also underpin the imprinting and path dependence theories. Our results further propose that the present capital structure and the debt structure research have a critical yet uncovered element of time-invariance and firm-explicit factors that are present from the establishment that drives the stability of the debt policy. Moreover, another finding of this study is that the consistency of debt policy for the firm subsidiary with a business group tends to decline at a marginally higher rate. Here, the declining rate for the consistency of the organizations associated with a financial firm in the business group is relatively slower. This fact underlines the need for further investigation on the firm's financial decision-making in the beginning stage, which goes beyond the conventional capital structure and the debt structure factors.

\section{Limitations and Future Research Directions}

The limitation of this study includes the unavailability of the data for two of the major variables. This includes the debt specialization from the year 1997 till 2008, which was an important recommended debt policy to consider while studying the consistency of the debt policy. Another limitation of this study is that the data was only available for two types of maturities, i.e., less than one year and more than one year for the debt maturity policy.

However, this study can also be generalized in other regions and geographies since the institutional and financial environment varies from country to country. The current context of the study is Pakistan, which is still a developing country. Furthermore, this study can be extended further so as to explore the in-depth understanding of each type of industry. In this manner, the consistency can be examined over the firm life cycle since this study is limited to the early stage of the firms' life cycle. 


\section{References}

Alderson, M. J., Bansal, N., \& Betker, B. L. (2014). Secured debt and managerial incentives. Review of Quantitative Finance and Accounting, 43(3), 423-440. doi: https://doi.org/10.1007/s11156013-0380-x

Alfaro, L., Asis, G., Chari, A., \& Panizza, U. (2019). Corporate debt, firm size and financial fragility in emerging markets. Journal of International Economics, 118(3), 1-19. doi:https:/ / doi.org/10.1016/ j.jinteco.2019.01.002

Berlin, M., Nini, G., \& Edison, G. Y. (2020). Concentration of control rights in leveraged loan syndicates. Journal of Financial Economics, 137(1), 249-271. doi:https://doi.org/10.1016/j.jfineco.2020.02.002

Borda, A., Geleilate, J.-M. G., Newburry, W., \& Kundu, S. K. (2017). Firm internationalization, business group diversification and firm performance: The case of Latin American firms. Journal of Business Research, 72(1), 104-113. doi:https://doi.org/10.1016/j.jbusres. 2016.11.006

Casino-Martínez, A., López-Gracia, J., Mestre-Barberá, R., \& PeiróGiménez, A. (2018). An agency approach to debt maturity of unlisted and listed firms in the European setting. European Management Journal, 37(3), 339-352. Doi: https://doi.org/10.1016/ j.emj.2018.07.008

Choi, Y. K., Han, S. H., \& Kwon, Y. (2019). CSR activities and internal capital markets: Evidence from Korean business groups. PacificBasin Finance Journal, 55(1), 283-298. doi:https:/ / doi.org/10.1016/ j.pacfin.2019.04.008

Cole, R. A., \& Sokolyk, T. (2018). Debt financing, survival, and growth of start-up firms. Journal of Corporate Finance, 50(6), 609-625. Doi: https://doi.org/10.1016/j.jcorpfin.2017.10.013

Danis, A., Rettl, D. A., \& Whited, T. M. (2014). Refinancing, profitability, and capital structure. Journal of Financial Economics, 114(3), 424-443. doi: https:/ / doi.org/10.1016/j.jfineco.2014.07.010 
David, P. A. (1985). Clio and the Economics of QWERTY. The American Economic Review, 75(2), 332-337. doi: https://www.jstor.org/ stable/1805621

Deloof, M., \& Vanacker, T. (2018). The recent financial crisis, start-up financing, and survival. Journal of Business Finance $\mathcal{E}$ Accounting, 45(7-8), 928-951. doi: https://doi.org/10.1111/jbfa.12319

Dudley, E., \& Yin, Q. E. (2018). Financial distress, refinancing, and debt structure. Journal of Banking $\mathcal{E}$ Finance, 94(9), 185-207. doi: https://doi.org/10.1016/j.jbankfin.2018.07.004

Ellouze, D., \& Mnasri, K. (2020). Business group diversification, financial constraints and firm performance: the case of Tunisian group affiliated firms. Journal of Management Governance, 24(1), 273-301. doi: https:/ /doi.org/10.1007/s10997-019-09454-4

Fan, J. P., Jin, L., \& Zheng, G. (2016). Revisiting the bright and dark sides of capital flows in business groups. Journal of Business Ethics, 134(4), 509-528. doi: https://doi.org/10.1007/s10551-014-2382-6

Gaur, A. S., Pattnaik, C., Singh, D., \& Lee, J. Y. (2019). Internalization advantage and subsidiary performance: The role of business group affiliation and host country characteristics. Journal of International Business Studies, 50(8), 1253-1282. doi: https://doi.org/10.1057/ s41267-019-00236-6

Ghouma, H. (2017). How does managerial opportunism affect the cost of debt financing? Research in International Business Finance, 39(1), 1329. doi: https://doi.org/10.1016/j.ribaf.2016.07.007

Goodell, J. W., \& Goyal, A. (2018). What determines debt structure in emerging markets: Transaction costs or public monitoring? International Review of Financial Analysis, 55(1), 184-195. doi: https://doi.org/10.1016/j.irfa.2017.07.004

Graham, J. R., Leary, M. T., \& Roberts, M. R. (2015). A century of capital structure: The leveraging of corporate America. Journal of Financial Economics, 118(3), 658-683. doi:10.1016/j.jfineco.2014.08.005.

Hanousek, J., \& Shamshur, A. (2011). A stubborn persistence: Is the stability of leverage ratios determined by the stability of the 
economy? Journal of Corporate Finance, 17(5), 1360-1376. doi: https://doi.org/10.1016/j.jcorpfin.2011.07.004

Hanssens, J., Deloof, M., \& Vanacker, T. (2016). The evolution of debt policies: New evidence from business start-ups. Journal of Banking E Finance, 65(3), 120-133. Doi: https://doi.org/10.1016/j.jbankfin. 2016.01.008

Hu, H. W., Cui, L., \& Aulakh, P. S. (2019). State capitalism and performance persistence of business group-affiliated firms: A comparative study of China and India. Journal of International Business Studies, 50(2), 193-222. doi: https://doi.org/10.1057/s41267-018-0165-5

Huang, Z., Gao, W., \& Chen, L. (2018). Does the external environment matter for the persistence of firms' debt policy?. Finance Research Letters, 32(1), 101073. doi: https:/ /doi.org/10.1016/j.frl.2018.12.021

Jara, M., Pinto-Gutiérrez, C., \& Núñez, P. (2018). The effects of ownership structure and intragroup loans on leverage: Evidence from family firms in Chile. Emerging Markets Finance and Trade, 54(11), 26142629. doi: https:/ / doi.org/10.1080/1540496X.2017.1369401

Joni, J., Ahmed, K., \& Hamilton, J. (2020). Politically connected boards, family and business group affiliations, and cost of capital: Evidence from Indonesia. The British Accounting Review, 52(3), 100878. doi: https://doi.org/10.1016/j.bar.2019.100878

Kayo, E. K., \& Kimura, H. (2011). Hierarchical determinants of capital structure. Journal of Banking $\mathcal{E}$ Finance, 35(2), 358-371. doi: https://doi.org/10.1016/j.jbankfin.2010.08.015

Khan, K. I., Qadeer, F., Mahmood, S., \& Rizavi, S. S. (2017). Reasons for debt specialization: Understanding the perspectives of small and large organizations, Lahore Journal of Business, 6(1), 93-110.

Khan, K. I., Qadeer, F., Mata, M. N., Chavaglia Neto, J., Martins, J. N., \& Filipe, J. A. (2021). Core predictors of debt specialization: A new insight to optimal capital structure. Mathematics, 9(9), 975. doi: https://doi.org/10.3390/math9090975

Khan, K. I., Qadeer, F., John, A., \& Sheeraz, M. (2016). Existence and prevalence of debt specialization strategy across organizations: A 
Pakistani perspective. Pakistan Journal of Commerce Social Sciences, 10(3), 461-485.

Khatua, A. (2017). Does business group affiliation matter for external debt finance? Evidence from India. Asian Business \& Management, 16(45), 290-322. doi: https:/ / doi.org/10.1057/s41291-017-0021-7

Kieschnick, R., \& Moussawi, R. (2018). Firm age, corporate governance, and capital structure choices. Journal of Corporate Finance, 48(2), 597614. doi: https://doi.org/10.1016/j.jcorpfin.2017.12.011

Kim, Y.-C., Shin, T., \& Park, S. (2019). Enhancing firm performance through intra-group managerial experience: Evidence from group-affiliated firms in Korea. Asia Pacific Journal of Management, 36(2), 1-31. doi: https: / / doi.org/10.1007/s10490-019-09671-3

Koralun-Bereźnicka, J. (2018). Firm size and debt maturity as indirect determinants of capital structure: evidence form European panel data. Applied Economics Letters, 25(18), 1319-1322. doi: https:/ / doi.org/10.1080/13504851.2017.1420869

Kwon, Y., Han, S. H., \& Lee, B.-S. (2016). Financial constraints and negative spillovers in business groups: Evidence from Korea. Pacific-Basin Finance Journal, 39(1), 84-100. doi: https:/ /doi.org/10.1016/j. pacfin.2016.05.003

La Rosa, F., Liberatore, G., Mazzi, F., \& Terzani, S. (2018). The impact of corporate social performance on the cost of debt and access to debt financing for listed European non-financial firms. European Management Journal, 36(4), 519-529. doi: https://doi.org/10.1016/j. emj.2017.09.007

Lemmon, M. L., Roberts, M. R., \& Zender, J. F. (2008). Back to the beginning: persistence and the cross-section of corporate capital structure. The Journal of Finance, 63(4), 1575-1608. doi: https://doi.org/10.1111/j.1540-6261.2008.01369.x

Lin, J. J., \& Yeh, Y.-H. (2020). InternalInternal capital markets, ownership structure, and investment efficiency: Evidence from Taiwanese business groups. Pacific-Basin Finance Journal, 60(1), 101284. doi: https://doi.org/10.1016/j.pacfin.2020.101284 
Liu, D., Wang, Y., \& Sun, C. (2019). Industrial policy, corporate strategic differences, and debt financing cost. Asia-Pacific Journal of Accounting Economics, 26(5), 1-17. doi: https:/ /doi.org/10.1080/ 16081625.2019.1673195

Malik, Q. U. Z., \& Afza, T. (2016). Do group affiliated firms specialize in debt? Evidence from Pakistan. Journal of Economic and Administrative Sciences, 32(1), 46-62. doi: https:/ /doi.org/10.1108/ JEAS-07-2015-0020

Martellini, L., Milhau, V., \& Tarelli, A. (2018). Capital structure decisions and the optimal design of corporate market debt programs. Journal of Corporate Finance, 49, 141-167.

Modigliani, F. and Miller, M. H. (1958). The cost of capital, corporation finance and the theory of investment. American Economic Review, 48(3), 261-297. doi: https://www.jstor.org/stable/1809766

Modigliani, F., \& Miller, M. H. (1963). Corporate income taxes and the cost of capital: a correction. American Economic Review, 53(3), 433-443. . doi: https://www.jstor.org/stable/1809167

Ni, J., Chu, L. K., \& Li, Q. (2017). Capacity decisions with debt financing: The effects of agency problem. European Journal of Operational Research, 261(3), 1158-1169. doi: https://doi.org/10.1016/j.ejor. 2017.02.042

Norden, L., Roosenboom, P., \& Wang, T. (2016). The effects of corporate bond granularity. Journal of Banking $\mathcal{E}$ Finance, 63(3), 25-34. doi: https://doi.org/10.1016/j.jbankfin.2015.11.001

Povoa, A. C. S. and Nakamura, W. T. (2014). Homogeneity versus heterogeneity in debt structure: A study using panel data. Accounting $\mathcal{E}$ Finance Review, 25(64), 19-32. doi: https://doi.org/10.1590/S1519-70772014000100003

Robb, A. M., \& Robinson, D. T. (2014). The capital structure decisions of new firms. The Review of Financial Studies, 27(1), 153-179. doi: https://doi.org/10.1093/rfs/hhs072 
Stinchcombe, A. L., March, J. G., 1965. Social structure and organizations. Advance Strategic Management, 17(1), 229-259. doi: https://doi.org/10.1016/S0742-3322(00)17019-6

Walthoff-Borm, X., Schwienbacher, A., \& Vanacker, T. (2018). Equity crowdfunding: first resort or last resort? Journal of Business Venturing, 33(4), 513-533. doi: https://doi.org/10.1016/j.jbusvent. 2018.04.001

Wang, H. D., \& Lin, C. J. (2013). Debt financing and earnings management: An internal capital market perspective. Journal of Business Finance $\mathcal{E}$ Accounting, 40(7-8), 842-868. doi: https://doi.org/10.1111/jbfa. 12030

Welch, I. (2004). Capital structure and stock returns. Journal of Political Economy, 112(1), 106-131.

Wu, X., \& Wang, Z. (2005). Equity financing in a Myers-Majluf framework with private benefits of control. Journal of Corporate Finance, 11(5), 915-945. doi: https://doi.org/10.1016/j.jcorpfin.2004.04.001

Wu, X., \& Yeung, C. K. A. (2012). Firm growth type and capital structure persistence. Journal of Banking $\mathcal{E}$ Finance, 36(12), 3427-3443. doi: https://doi.org/10.1016/j.jbankfin.2012.08.008 
